\title{
Temel Konularda BOBİ FRS ve TMS/TFRS Karşılaştırması
}

\author{
Ümit GÜCENME GENÇOĞLU *
}

\section{ÖZET}

Kamu Gözetimi Kurumu(KGK) tarafindan 29 Temmuz 2017 tarihinde Resmi Gazete'de yayımlanan 'Büyük ve Orta Boy Isşletmeler için Finansal Raporlama Standardı (BOBI FRS)'nin, "Türkiye Muhasebe /Finansal Raporlama Standartlart (TMS/TFRS)" ile temel konularda karşılaştırılması ve faklılıkların ortaya konması, bu çalışmanın amacını oluşturmaktadır. Genel olarak TMS/TFRS'ler ile uyumlu, daha sade bir dille kaleme alınmış olan BOBI FRS'de, kapsama alınmayan standartlar bulunduğundan ve uygulama kolaylıklart sağlandığından, iki standart seti arasında bazı farklılıklar ortaya çıkmaktadır. Kapsamlı kar kavraminın kullanılmadığ BOBI FRS'de finansal durum tablosu, kar zarar tablosu ve özkaynak değişim tablosu formatında farklılıklar bulunmaktadır. Orta büyüklükteki işletmelerde genel olarak maliyet esaslı bir finansal raporlama getirilmiş, büyük işletmeler için finansal tablo kalemlerinin ölçümünde gerçeğe uygun değer kavramı korunmuş ve büyük işletmelere yönelik bazı ilâve yükümlülükler getirilmiştir.

Anahtar Kelimeler: Faydall finansal bilgi, gerçeğe uygun değer, finansal raporlama standartlarl

JEL Sinıflandırması: M40, M41.

\section{Comparison of the Differences between BOBI FRS and TAS / TFRS}

\section{ABSTRACT}

The purpose of this study is to compare and to determine the differences between "Financial Reporting Standard for Large and Medium Size Enterprises (BOB FRS)" and Turkish Accounting / Financial Reporting Standards (TAS / TFRS). BOBI FRS does not use the concept of comprehensive profit and does not cover some standards. Therefore, there are differences in the format of the financial position table and the profit and loss statement in particular. Medium-sized enterprises generally have cost-based financial reporting, the concept of fair value is maintained in the measurement of financial statement items for large enterprises and some additional obligations have been introduced for large enterprises.

Keywords: Useful financial information, true and fair value, financial reporting standards.

Jel Classification: M40, M41.

\footnotetext{
* Prof.Dr.Ümit Gücenme Gençoğlu, Uludağ Üniversitesi,İktisadi ve İdari Bilimler Fakültesi, umitgucenme@uludag.edu.tr
} 


\section{GİRiş}

Bağımsız denetime tâbi olup Türkiye Muhasebe/ Finansal Raporlama Standartlarını (TMS/TFRS) uygulamayan işletmelerin uygulayacakları finansal raporlama çerçevesi olan "Büyük ve Orta Boy İşletmeler için Finansal Raporlama Standardı (BOBİ FRS)" , Kamu Gözetimi Kurumu (KGK) tarafından 29 Temmuz 2017 tarihli ve 30138 Sayılı Mükerrer Resmi Gazete'de yayımlanmıştır. KGK'nın, 2014 yılındaki bir kararı ile TMS/TFRS uygulamaları sadece Kamu Yararını İlgilendiren Kuruluşlar(KAYİK) için zorunlu tutulmuş, TMS/TFRS uygulamayan işletmelerin ise KGK tarafından bir belirleme yapılıncaya kadar Muhasebe Sistemi Uygulama Genel Tebliğleri ( MSUGT)’ni, 29/12/2014 tarihli ve 41 sayıl1 KGK Kararıyla açıklanan "TMS'leri Uygulamayan Şirketlerin Finansal Tablolarının Hazırlanmasinda Uygulanacak Ilave Hususlar” ile birlikte uygulayarak raporlama yapması istenmiştir. Ancak TMS/TFRS'ler ile Muhasebe Sistemi Uygulama Genel Tebliğleri uyumlu olmadığından, bağımsız muhasebe denetiminde, işletme finansal tablolarının doğruluğunu tespit etmek için iki farklı karşılaştırma kriteri ( çifte standart) kullanılması sakıncası ortaya çıkmıştır. Bu nedenle KGK, 2014 yılından itibaren başlattığı TMS/TFRS'ler ile uyumlu yeni bir raporlama çerçevesi oluşturma çalışmalarını 2017 Temmuz sonunda tamamlamıştır. 1/1/2018 tarihi ve sonrasında başlayan hesap dönemlerinde uygulanmak üzere, yayımı tarihinde yürürlüğe giren ve uluslararası standartlarda bir finansal raporlama çerçevesi olan BOBİ FRS, KAYİK'ler dışındaki bağımsız denetime tâbi tüm şirketlerin bağımsız denetimlerinde kıstas oluşturacak, bağımsız denetimde çifte standart uygulanması sakıncasını ortadan kaldıracaktır.

BOBİ FRS'nin yer aldığı 'Büyük ve Orta Boy İşletmeler İçin Finansal Raporlama Standardı Hakkında Tebliğ'de büyük işletme tanımı bulunmaktadır. Buna göre, aktif toplamı 75 milyon ve üstü, yıllık net satış hasılat1 150 milyon ve üstü Türk Lirası ve ortalama çalışan sayıs1 250 ve üstü olan ve bu üç ölçütten en az ikisinin eşik değerlerini, varsa bağlı ortaklıklarıyla birlikte, art arda iki raporlama döneminde aşan işletmeler müteakip raporlama döneminde büyük işletme olarak değerlendirilir. Bu ölçütlerin altında kalan, ancak denetime tabi olma koşullarını karşılayan işletmeler ise standartta orta boy işletmelerin uyması gereken kurallara göre finansal raporlama yapacaktır.

Uluslararası muhasebe ve finansal raporlama uygulamalarıyla ve $\mathrm{AB}$ düzenlemeleriyle uyumlu olan ve 27 bölümden oluşan BOBİ FRS'de, orta büyüklükteki işletmeler için genel olarak maliyet esaslı bir finansal raporlama öngörülmüş; büyük işletmelere yönelik ise ilâve yükümlülükler getirilmiştir. Bu çalışmada temel konularda BOBİ FRS ile TMS/TFRS'ler karşılaştırılarak, benzer ve farklı yönleri ortaya konmaya çalışılacaktır. Aşağıdaki tabloda BOBİ FRS'deki her bölümün hangi TMS/TFRS kapsamındaki düzenlemelere yer verdiği özetlenmiştir. BOBİ FRS'de, bazı TMS/TFRS'lere ilişkin düzenleme yer almamaktadır. 


\begin{tabular}{|c|c|}
\hline BOBİ FRS Bölümler & TMS/TFRS \\
\hline Bölüm 1 Kavramsal Çerçeve ve Finansal Tablolar & $\begin{array}{l}\text { Finansal Raporlamaya İlişkin Kavramsal Çerçeve } \\
\text { TMS } 1 \text { Finansal Tabloların Sunuluşu }\end{array}$ \\
\hline Bölüm 2 Nakit Akış Tablosu & TMS 7 Nakit Akış Tabloları \\
\hline Bölüm 3 Muhasebe Politikaları, Tahminler ve Yanlışlıklar & $\begin{array}{l}\text { TMS } 8 \text { Muhasebe Politikaları, Muhasebe Tahminlerinde } \\
\text { Değişiklikler ve Hatalar }\end{array}$ \\
\hline Bölüm 4 Raporlama Döneminden Sonraki Olaylar & $\begin{array}{l}\text { TMS } 10 \text { Raporlama Döneminden (Bilanço Tarihinden) } \\
\text { Sonraki Olaylar }\end{array}$ \\
\hline Bölüm 5 Hasılat & $\begin{array}{l}\text { TMS } 18 \text { Hasılat } \\
\text { TMS } 11 \text { İnşaat Sözleşmeleri } \\
\text { TFRS } 15 \text { Müşteri Sözleşmelerinden Hasılat }\end{array}$ \\
\hline Bölüm 6 Stoklar & TMS 2 Stoklar \\
\hline Bölüm 7 Tarımsal Faaliyetler & TMS 41 Tarımsal Faaliyetler \\
\hline $\begin{array}{l}\text { Bölüm } 8 \text { Maden Kaynaklarının Aranması ve } \\
\text { Değerlendirilmesi }\end{array}$ & $\begin{array}{l}\text { TFRS } 6 \text { Maden Kaynaklarının Araştırılması ve } \\
\text { Değerlendirilmesi }\end{array}$ \\
\hline Bölüm 9 Finansal Araçlar Ve Özkaynaklar & $\begin{array}{l}\text { TFRS } 7 \text { Finansal Araçlar: Açıllamalar } \\
\text { TMS } 32 \text { Finansal Araçlar: Sunum } \\
\text { TMS } 39 \text { Finansal Araçlar } \\
\text { TFRS } 9 \text { Finansal Araçlar }\end{array}$ \\
\hline Bölüm 10 İştiraklerdeki Yatırımlar & TMS 28 İştiraklerdeki ve İş Ortaklıklarındaki Yatırımlar \\
\hline Bölüm 11 Müşterek Girişimlerdeki Yatırımlar & TFRS 11 Müşterek Anlaşmalar \\
\hline Bölüm 12 Maddi Duran Varlıklar & TMS 16 Maddi Duran Varlıklar \\
\hline Bölüm 13 Yatırım Amaçlı Gayrimenkuller & TMS 40 Yatırım Amaçlı Gayrimenkuller \\
\hline Bölüm 14 Maddi Olmayan Duran Varlıklar & TMS 38 Maddi Olmayan Duran Varlıklar \\
\hline Bölüm 15 Kiralamalar & TMS 17 Kiralama İşlemleri \\
\hline Bölüm 16 Devlet Teşvikleri & $\begin{array}{l}\text { TMS } 20 \text { Devlet Teşviklerinin Muhasebeleştirilmesi ve } \\
\text { Devlet Yardımlarının Açıklaması }\end{array}$ \\
\hline Bölüm 17 Borçlanma Maliyetleri & TMS 23 Borçlanma Maliyetleri \\
\hline Bölüm 18 Varlıklarda Değer Düşüklüğü & TMS 36 Varlıklarda Değer Düşüklüğü \\
\hline $\begin{array}{l}\text { Bölüm } 19 \text { Karşılıklar, Şarta Bağlı Yükümlülükler ve Şarta } \\
\text { Bağlı Varlıklar }\end{array}$ & TMS 37 Karş1lıklar, Koşullu Borçlar ve Koşullu Varlıklar \\
\hline Bölüm 20 Yabancı Para Çevrim İşlemleri & TMS 21 Kur Değişiminin Etkileri \\
\hline Bölüm 21 İş Birleşmeleri & TFRS 3 İşletme Birleşmeleri \\
\hline Bölüm 22 Konsolide Finansal Tablolar & TFRS 10 Konsolide Finansal Tablolar \\
\hline Bölüm 23 Gelir Üzerinden Alınan Vergiler & TMS 12 Gelir Vergileri \\
\hline Bölüm 24 Ara Dönem Finansal Raporlama & TMS 34 Ara Dönem Finansal Raporlama \\
\hline $\begin{array}{l}\text { Bölüm } 25 \text { Yüksek Enflasyonlu Ekonomilerde Finansal } \\
\text { Raporlama }\end{array}$ & $\begin{array}{l}\text { TMS } 29 \text { Yüksek Enflasyonlu Ekonomilerde Finansal } \\
\text { Raporlama }\end{array}$ \\
\hline Bölüm 26 Dipnotlar & TMS 1 Finansal Tabloların Sunuluşu \\
\hline Bölüm 27 Geçiş Hükümleri & $\begin{array}{l}\text { TFRS } 1 \text { Türkiye Finansal Raporlama Standartlarının İlk } \\
\text { Uygulaması }\end{array}$ \\
\hline
\end{tabular}

Aşağıdaki TMS/TFRS'ler, BOBİ FRS'de ayrı bölüm olarak bulunmamakta, ancak bazı standartlardaki düzenlemelerin sadeleştirilmiş şekli diğer bölümler içinde yer almaktadır. Örneğin TMS 27 "Bireysel Finansal Tablolar” BOBİ FRS'de ayrı bölüm olarak ele alınmamış olmakla birlikte finansal yatırımların münferit finansal tablolarda nasıl raporlanacağı ilgili bölümler içinde açıklanmıştır. 


\begin{tabular}{|l|}
\hline TFRS 2 Hisse Bazlı Ödemeler \\
\hline TFRS 4 Sigorta Sözleşmeleri \\
\hline TFRS 5 Satı̧̧ Amaçlı Elde Tutulan Duran Varlıklar ve Durdurulan Faaliyetler \\
\hline TFRS 8 Faaliyet Bölümleri \\
\hline TFRS 12 Diğer İşletmelerdeki Paylara İlişkin Açıklamalar \\
\hline TFRS 13 Gerçeğe Uygun Değer Ölçümü \\
\hline TFRS 14 Düzenlemeye Dayalı Erteleme Hesapları \\
\hline TMS 19 Çalış̧anlara Sağlanan Faydalar \\
\hline TMS 24 İlişkili Taraf Açıllamaları \\
\hline TMS 26 Emeklilik Fayda Planlarında Muhasebeleştirme Ve Raporlama \\
\hline TMS 27 Bireysel Finansal Tablolar \\
\hline TMS 33 Hisse Başına Kazanç \\
\hline
\end{tabular}

\section{FINANSAL RAPORLAMA}

BOBİ FRS Bölüm 1'de yer alan kavramsal çerçeve ve finansal tablolar ile ilgili düzenlemeler genel olarak TMS/TFRS düzenlemeleri ile uyumludur. Buna göre, bir finansal bilginin faydalı olması için temel olarak, bilgiyi kullanacakların ihtiyacına ve işletme gerçeklerine uygun olmalı ve ayrıca bu bilgiler zamanında sunulmalı, anlaşılabilir ve karşılaştırılabilir olmalıdır. Yönetimin, işletmeyi tasfiye etme veya ticari faaliyetlerine son verme niyetinin ya da zorunluluğunun bulunmadığı durumlarda finansal tablolar işletmenin sürekliliği varsayımına dayanılarak hazırlanır. Nakit akış tablosu hariç, tüm finansal tablolar tahakkuk esasına göre düzenlenir. İhtiyatlılık ilkesine uyularak, belirsizlikler nedeniyle tahmin yapılması gereken hallerde varlık ve gelirlerin olduğundan daha fazla, yükümlülük ve giderlerin ise olduğundan daha düşük belirlenmemesi için gerekli dikkatin gösterilmesi gerekir. Her bir önemli hesap sınıfı finansal tablolarda ayrı olarak gösterilir ve bu standartlarda zorunlu tutulan veya izin verilen hâller dışında, varlık ve yükümlülükler veya gelir ve giderler birbirlerinden mahsup edilemez.

TMS/TFRS'lerde olduğu gibi finansal durum tablosu, kâr veya zarar tablosu, nakit akış tablosu, özkaynak değişim tablosu ve önemli muhasebe politikalarını ve diğer açıklayıcı bilgileri içeren dipnotlar, bu Standart hükümlerine uygun olarak, açık ve anlaşılır bir şekilde hazırlanır. Varlık ve yükümlülüklerin tanımı ve finansal durum tablosunda yer alabilmesi için gerekli koşullar iki standart setinde aynıdır. BOBİ FRS'ye göre, gerçeğe uygun değer gibi başka bir ölçüm esası belirlenmediği sürece, varlık ve yükümlülükler ilk kayda almada maliyet bedeliyle (tarihi maliyet) ölçülür. BOBİ FRS'de gerçeğe uygun değer, "karşılıklı pazarlık ortamında, bilgili ve istekli taraflar arasında bir varlığın el değiştirmesi ya da bir yükümlülügün yerine getirilmesi durumunda ortaya çıkabilecek tutar” olarak tanımlanmış, finansal araçlar, tarımsal faaliyetler ve maddi duran varlıklar bölümlerinde gerçeğe uygun değerin nasıl belirleneceğine ilişkin açıklamalar yapılmıştır. 
BOBİ FRS eklerinde yer alan finansal durum tablosu, kar zarar tablosu, özkaynak değişim tablosu ve nakit akış tablosu formatları genel olarak TMS/TFRS'ler ile uyumlu olmakla birlikte bazı farklar bulunmakta, en fazla fark da kar zarar tablosunda görülmektedir. Kavramsal çerçeve ve finansal tabloların kapsamı açısından TMS/TFRS'ler ile daha sade olan BOBİ FRS arasındaki farklılıklar aşağıdaki gibi özetlenebilir.

- TFRS 5 konusu olan "Satı̧s Amaçlı Elde Tutulan Duran Varlıklar ve Durdurulan Faaliyetler", BOBİ FRS'de yer almadığından kar zarar tablosunda da sürdürülen ve durdurulan faaliyet sonuçları ayrı ayrı raporlanmaz. Tabloda brüt kar/zararı takiben esas faaliyetlerden gelirler/giderler, diğer faaliyetlerden gelirler/giderler ve finansal gelirler/giderler eklenip çıkartılır.

- TMS 19 kapsamındaki "Çalı̧̧anlara Sağlanan Faydalar" ve "TMS 26 Emeklilik Fayda Planlarında Muhasebeleştirme ve Raporlama" BOBİ FRS'de ayrı bölüm olarak yer almadığından, BOBİ FRS'ye göre hazırlanan finansal durum tablosunda sadece kısa ve uzun vadeli yabancı kaynaklar içinde "kıdem tazminatı karşılıkları" kalemi bulunmaktadır. BOBİ FRS BÖLÜM 19'da, tam set standartlardaki aktüeryal hesaplamalar yerine, gerek karşılıkların, gerek kıdem tazminatının hesaplanmasında kolaylaştıııcı yöntemlere yer verildiği görülmektedir.

- BOBİ FRS'ye göre büyük işletmeler ertelenmiş vergileri hesaplar ve raporlar ancak, orta büyüklükteki işletmelerin ertelenmiş vergileri bireysel finansal tablolarında raporlaması zorunlu değildir. Buna ilişkin BOBİ FRS Bölüm 23/3'de " Büyük işletmelerin konsolide ve münferit finansal tablolarında ertelenmiş vergi tutarlarını sunmaları zorunludur. Ancak diğer işletmelerin ertelenmiş vergi tutarlarını finansal tablolarında sunmaları şart değildir. Bununla birlikte, bu işletmelerin isteğe bağlı olarak konsolide finansal tablolarını hazırlamaları durumunda, ertelenmiş vergi tutarlarını sunmaları konsolide finansal tablolarında zorunlu, ancak münferit finansal tablolarında ihtiyaridir. Büyük işletmelerin ertelenmiş vergileri hesaplaması ve raporlaması ile ilgili düzenlemeler ise TMS 12 ile uyumludur. BOBİ FRS madde 23.40'a göre, "Ertelenmiş vergi yükümlülüğü veya varlı̆ı̆nda meydana gelen değişimler vergi gideri/geliri olarak raporlanır. Ertelenmiş vergi gideri/geliri Kâr veya Zarar Tablosunda "Vergi Gideri" kalemi içerisinde gösterilir. Ancak ertelenmiş vergi giderinin/gelirinin, kâr veya zarara yansıtılmayan (diğer bir ifadeyle özkaynaklarda kayda alınan) işlem veya olayların sonucu olarak ortaya çıkması durumunda bunlara ilişkin ertelenmiş vergi tutarı, söz konusu işlem ve olayların etkilerinin yansıtıldığı özkaynak kaleminde gösterilir." Ayrıca TMS 12'de olduğu gibi, finansal durum tablosunda duran varlıklar kapsamında "ertelenmiş vergi varlı̆ı"”, uzun vadeli yükümlülükler kapsamında "ertelenmiş vergi yükümlülüğü̈" raporlanmaktadır.

- TMS 1'deki diğer kapsamlı gelir tablosu, BOBİ FRS'de yer almamıştır. Kâr veya Zarar Tablosunun unsurları gelirler ve giderlerdir. Gelirler; ortakların yaptığı katkılar hariç olmak üzere, varlık girişi veya varlıkların değerinde artış ya da yükümlülüklerde azalma 
şeklinde özkaynaklarda raporlama dönemi boyunca meydana gelen artıştır. Giderler ise, ortaklara yapılan dağıtımlar hariç olmak üzere, varlık çıkışı veya varlıkların değerinde azalış ya da yükümlülüklerde artış şeklinde özkaynaklarda raporlama dönemi boyunca meydana gelen azalıştır. Bu tanımlar iki standart setinde de müşserek olmakla birlikte BOBİ FRS'de kapsamlı gelir tanımı yer almamakta, TFRS 1'e göre hazırlanan finansal durum tablosunda yer alan "Kar Zararda Yeniden Sinıflandırılacak/Sinıflandırılmayacak Diğer Kapsamlı Gelirler/Giderler", BOBİ FRS'e göre hazırlanan finansal durum tablosunda ve özkaynak değişim tablosunda bulunmamaktadır. BOBİ FRS finansal durum tablosunda özkaynaklar kapsamında sadece "Yeniden Değerleme Yedeği, Yabancı Para Çevrim Farkları ve Korunma Yedeği" yer almakta, bu kalemler özkaynak değişim tablosunda da raporlanmaktadır. Kar zarar tablosunda ise, "Diğer Faaliyetlerden Gelir Ve Giderler" içinde yatırım amaçlı gayrimenkul değer artış ve azalışları ile "Finansal Gelir / Giderler" içinde finansal yatırımlar değer artış ve azalışları yer almaktadır.

BOBİ FRS 3. bölümde yer alan "Muhasebe Politikaları, Tahminler ve Yanlışlıklar" TMS 8 ile uyumlu düzenlemeler içermektedir. Bu Standartta herhangi bir işlem veya olay için belirlenmiş bir muhasebe politikası varsa bu muhasebe politikası uygulanır. İsteğe bağlı muhasebe politikasındaki değişiklik geçmişe dönük olarak uygulanır ve politika değişikliğinden etkilenen her kalem ile özkaynak kalemi mümkün olduğu kadar geriye giderek düzeltilir. Düzeltme "geçmiş yıllar karları" kalemine yapılır. Geçmişe dönük uygulama, açılış ve kapanış bilançosuna ait kümülatif etkinin hesaplanabildiği durumlarda uygulanabilir. Geçmiş dönemler için kümülatif etkinin belirlenmesi mümkün değilse, ilgili değişiklik geriye dönük uygulamanın mümkün olduğu en erken dönemin başında(bu cari dönem de olabilir) mevcut olan varlık, borç özkaynak kalemlerinin açılış bakiyelerine uygulanır. Yeni muhasebe politikasının önceki tüm dönemlere uygulanması sonucu cari dönemin başında ortaya çıkacak birikimli etkinin belirlenmesi mümkün değilse ilgili değişiklik, uygulamanın mümkün olduğu en erken tarihten itibaren ileriye yönelik olarak uygulanır. $\mathrm{Bu}$ durumda, politika değişikliğinin bu tarihten önceki varlık, yükümlülük ve özkaynak kalemlerine birikimli etkisi dikkate alınmamış olur. Muhasebe tahminlerindeki değişikliğin etkileri ileriye dönük olarak uygulanır ve muhasebe tahmini değişikliğinin etkisi ileriye dönük olarak, kar veya zarar ile ilişkilendirilir. Cari dönemde yapılan yanlışlıklar finansal tablolar onaylanmadan önce tespit edilirse cari dönemde düzeltilir. Ancak bazı durumlarda yanlışlıklar yapıldığı dönemde fark edilmeyebilir; bunlar geçmiş dönem yanlışlıkları olarak nitelendirilir. Önemli geçmiş dönem yanlışlıkları geriye dönük olarak düzeltilir.

BOBİ FRS Bölüm 4'de, TMS 10 paralelinde finansal durum tablosu tarihinden sonraki olaylar tanımlanmakta ve bu olaylara ilişkin muhasebe ilkeleri düzenlenmektedir. Raporlama döneminden sonraki olaylar, raporlama dönemi sonu ile finansal tabloların yönetim organı tarafından onaylandığı tarih arasında işletme lehine veya aleyhine ortaya çıkan olayları ifade eder. Raporlama döneminden sonraki olaylar düzeltme gerektiren ve düzeltme gerektirmeyen 
olaylar şeklinde ikiye ayrılır. Raporlama döneminden sonraki düzeltme gerektiren olaylar raporlama dönemi sonu itibarıla mevcut olan durumları teyit eden olaylardır ve bu olayların etkisinin yansıtılması amacıyla ilgili dipnotlar dâhil raporlama dönemine ait finansal tablolarda yer alan tutarlar düzeltilir.

\section{FINANSAL VARLIK VE YÜKÜMLÜLÜKLER}

TMS/TFRS'lerdeki finansal araçlar ile ilgili ayrıntılı düzenlemeler BOBİ FRS'de 9, 10 ve 11. bölümlerde sadeleştirilmiştir. Finansal durum tablosu formatında dönen ve duran varlıklar içinde yer alan finansal yatırımlar için ayrıntı yer almamaktadır BOBİ FRS 9. bölümde, finansal araçlar, "bir işletmenin bir finansal varlığının, başka bir işletmenin de bir finansal yükümlülüğünün veya özkaynak aracının artmasına neden olan sözleşmedir "şeklinde tanımlanmaktadır. Bu bölümde finansal varlık ve finansal yükümlülüklere ilişkin muhasebe ilkeleri ve işletmenin ihraç ettiği özkaynak araçlarının muhasebeleştirilme esasları düzenlenmektedir. Finansal varlık tanımı, TMS/TRS'lerde olduğu gibi menkul kıymetler ile nakit ve alacakları da kapsamaktadır. Ödeme çağrısı yapılan sermaye alacakları ile ilk defa kayda alındığı tarihle tahsil edileceği veya ödeneceği tarih arasında bir yıl veya daha kısa süre olan alacak ve borçlar itibari değeri ile, bir yıldan uzun olan alacaklar (ödeme çağrısı yapılan sermaye alacakları hariç) ve borçlar ise itfa edilmiş değeri üzerinden ölçülür.( madde 9.8) Ticari ve diğer alacaklar ile ticari ve diğer borçlar dişında kalan ve sabit bir tutar, sabit yada değişken ve sabit bileşenlerden oluşan bir getiri oranı veya kote edilmiş, gözlemlenebilir bir faiz oranı olan borçlanma araçları itfa edilmiş değeri üzerinden ölçülür. (madde 9.11) Borçlanma aracı niteliğindeki finansal varlıklara örnek olarak, bankalardaki vadeli mevduatlar, devlet tahvili, hazine bonosu veya özel sektör tahvil ve bonoları; finansal yükümlülüklere örnek olarak ise alınan krediler, ihraç edilen tahvil ve bonolar gösterilebilir. (madde 9.13) Bir finansal varlık veya yükümlülügün her bir raporlama dönemi sonu itibarıyla itfa edilmiş değeri aşağıdakilerin net tutarıdır ( madde 9.14):

a) Finansal varlığın veya finansal yükümlülügün ilk kayda alma sırasında belirlenen değeri,

b) Eksi anapara geri ödemeleri,

c) Artı veya eksi ilk defa finansal tablolara alındığındaki tutar ile vadesindeki tutar arasındaki fark üzerinden etkin faiz yöntemi kullanılarak hesaplanan toplam itfa tutarı,

ç) Eksi, finansal varlıklar için, değer düşüklüğü veya tahsil edilememe olasılığından kaynaklanan tüm indirimler.

Finansal varlığa veya finansal yükümlülüğe (veya finansal araçlar grubuna) ilişkin defter değeri yeniden gözden geçirildiğinde, gerçek ve gözden geçirilmiş tahmini nakit akışlarını yansıtacak şekilde düzeltilir. Finansal aracın defter değeri, başlangıçtaki etkin faiz oranı kullanılarak gelecekteki tahmini nakit akışlarının bugünkü değeri bulunmak suretiyle yeniden hesaplanır. Düzeltme, gözden geçirmenin yapıldığı tarihte, Kâr veya Zarar 
Tablosunda "Finansal Yatırımlar Değer Artış Kazançları" veya "Finansal Yatırımlar Değer Azalış Zararları” kaleminde gösterilir.( madde 9.19)

Borsada ve/veya teşkilatlanmış diğer piyasalarda işlem gören özkaynak araçları, ilk muhasebeleştirmede işlem fiyatından ölçülerek işlem maliyetleri kâr veya zarara yansıtılır. $\mathrm{Bu}$ özkaynak araçları raporlama tarihinde ise gerçeğe uygun değerleri (piyasa değeri) üzerinden ölçülür ve ortaya çıkan değer farkları "Finansal Yatırımlar Değer Artış Kazançları" veya "Finansal Yatırımlar Değer Azalış Zararları" kalemlerinde kâr veya zarara yansıtılır. Borsada ve/veya teşkilatlanmış diğer piyasalarda işlem görmeyen özkaynak araçları, ilk muhasebeleştirmede, işlem fiyatları ve işlem maliyetlerinin toplamından oluşan maliyet bedelinden ölçülür. Bu özkaynak araçları sonraki raporlama tarihlerinde maliyet bedelinden varsa değer düşüklüğü zararları düşülerek ölçülür.( madde 9.21) Bir başka deyişle borsada işlem gören hisse senetleri GUD ile değerlenir, değerleme farkları (TMS/TFRS'de bazı durumlarda özkaynaklarda kayıtlanabildiği halde) burada her zaman kar zarara yollanır. Borsada işlem görmeyen hisse senetleri ise, maliyet yöntemi ile değerlenir ve sadece değer azalışları gider olarak kar zarara yollanır. İşletme, korunma aracı ile korunan kalem arasında korunma ilişkisi tanımlayarak korunma muhasebesini ihtiyari olarak uygulayabilir. İtfa edilmiş bedeli üzerinden ölçülen bir borçlanma aracının sabit faiz oranı riskinden korunması durumunda, faiz oranı swapı niteliğindeki korunma aracına ilişkin dönemsel net nakit ödemeleri, bu ödemelerin tahakkuk ettiği dönemde kâr veya zarara yansitılır.( madde 9.50) Korunulan riskin madde 9.53'dekilerden biri olması durumunda, korunma aracının gerçeğe uygun değerindeki değişimin, korunan kalemin gerçeğe uygun değerindeki veya beklenen nakit akışlarındaki değişimleri etkin olarak karşılayan kısmı, özkaynaklarda "Korunma Yedeği" kaleminde muhasebeleştirilir.

Buna göre tam set standartlardan farklı olarak, BOBİ FRS'de tüm finansal varlık ve yükümlülüklerdeki değerleme farkları kar zarar tablosunda raporlanırken, sadece koşulları belirlenen türev araçlardaki değerleme farklarının özkaynaklarda raporlanması söz konusudur.

İștirakler ve bağlı ortaklıklar, münferit finansal tablolarda maliyet yöntemi veya özkaynak yöntemi ile, konsolide finansal tablolarda ise iştirakler özkaynak yöntemi kullanılarak ölçülür.(madde 10.10) Özkaynak yönteminin önemli etkiye sahip olunan iştirakler için kullanılması gerektiğine ilişkin bir kısıtlama bulunmamaktadır. Bir işletmenin, yatırım yaptığı işletmenin oy hakkının yüzde 20 ya da daha fazlasını, doğrudan ya da dolaylı olarak (örneğin bağlı ortaklıkları vasıtasıyla) elinde tutması durumunda, aksi açıkça ortaya konulamadığı sürece, yatırım yapılan işletme üzerinde önemli etkisinin bulunduğu kabul edilir. Tam set standartlarda olduğu gibi maliyet yönteminde, hesaplanan değer düşüklüğü kar zarar tablosunda raporlanır, finansal durum tablosunda ise, birikmiş değer düşüklüğü zararları indirilerek maliyet bedelleri üzerinden ölçülür. Özkaynak yönteminin kullanıldığı durumlarda iştirak yatırımının defter değeri, iştirakin;

a) Dönem net kârından (zararından) ve 
b) Cari dönemde özkaynaklarında (örneğin "Yeniden Değerleme Yedeği”, "Yabancı Para Çevrim Farkları" ve "Korunma Yedeği” kalemlerinde) kaydettiği kazanç ve kayıplarından, işletmeye düşen pay kadar artırılır veya azaltılır.( madde 10.19)

BOBİ FRS 11. bölümde müşterek girişimler ele alınmış, oluşum biçimlerine göre müştereken kontrol edilen faaliyetler, müştereken kontrol edilen varlıklar veya müştereken kontrol edilen işletmeler olmak üzere üç farklı türde sınıflandırılmış ve her birine ilişkin muhasebe ilkeleri belirlenmiştir. 21. bölümde ise işletme birleşmeleri ile ilgili genel olarak TFRS 3 ile uyumlu düzenlemeler bulunmaktadır. Ancak TFRS 3'ten farklı olarak şerefiye değer düşüklüğü testine tâbi tutulmaz. Şerefiyeye ilişkin itfa payının hesaplanmasında "Maddi Olmayan Duran Varlıklar" bölümünün "İtfa" başlıklı kısmında yer alan hükümler uygulanır. Şerefiyenin faydalı ömrünün güvenilir bir şekilde tahmin edilemediği durumlarda şerefiye 10 yilda itfa edilir. BOBİ FRS 22. bölümde, TFRS 10 ile uyumlu olarak bağlı ortaklık, kontrol gücü ve konsolide finansal tablolar tanımlanmış ve ilgili düzenlemeler yapılmıştır. Buna göre, büyük işletmeler, bağlı ortaklıklarını bu bölümde yer alan konsolidasyon işlemlerini uygulayarak (tam konsolidasyon yöntemine göre) konsolide eder ve konsolide finansal tablolarını düzenler. Konsolide finansal tablolar, ana ortaklığın ve onun bağlı ortaklıklarının varlıklarının, yükümlülüklerinin, özkaynaklarının, gelirlerinin, giderlerinin ve nakit akışlarının tek bir işletmeninki gibi sunulduğu, bir topluluğa ait finansal tablolardır. (madde 22.14) Büyük işletme dışındaki işletmeler konsolide finansal tablo düzenlemek zorunda değildir. Bununla birlikte bu işletmeler isteğe bağlı olarak konsolide finansal tablolarını hazırlayabilir.(madde 22.10) Ancak ana ortaklık büyük işletme olmasa dahi, doğrudan veya dolaylı olarak sahip olduğu herhangi bir bağlı ortaklığının 660 sayılı KHK' da tanımlanan Kamu Yararını İlgilendiren Kuruluş( KAYİK) tanımını karşılaması ve bu bağlı ortaklığın 22.18 paragrafında belirtilen bir bağlı ortaklık olmaması durumunda konsolide finansal tablolarını hazırlar. (madde 22.11) Konsolide finansal tablo hazırlamayan işletmeler bağlı ortaklıklarındaki yatırımlarını maliyet yöntemi veya özkaynak yöntemi kullanarak muhasebeleştirir. (madde 22.12)

\section{HASILATIN RAPORLANMASI}

BOBİ FRS 5. bölümde hasılat, işletmenin olağan faaliyetleri esnasında ortaya çıkan gelir olarak tanımlanmakta ve bölüm kapsamında mal satışı, hizmet sunumu, işletmenin yüklenici olduğu inşa sözleşmeleri ile işletme varlıklarının başkaları tarafından kullanılmasından sağlanan faiz, isim hakkı ve kâr payı bulunmaktadır. $\mathrm{Bu}$ bölüm düzenlemeleri, 9 Eylül 2016 Tarihli Resmi Gazete'de yayımlanarak Türkiye Finansal Raporlama Standartları arasında yer alan ve 1 Ocak 2018 tarihinde ve sonrasında başlayan yıllık raporlama dönemleri için geçerli olmak üzere TMS 11 'İnşaat Sözleşmeleri' ve UMS 18 Hasılat Standardını yürürlükten kaldıran TFRS 15 ile karşılaştırıldığında çok daha sadedir. BOBİ FRS'de hasılat ile ilgili düzenlemeler genel olarak TMS 18 ile aynı paraleldedir. TMS 18'de hasılat kapsamındaki faiz ve temettü gelirleri TFRS 15 kapsamı dışında bırakılmış 
olmasına karşılık BOBİ FRS bölüm 5 kapsamındadır. “TFRS 15’in temel prensibi, şirketlerin geliri, mal veya hizmetleri müşterilerine devretmesi karşılığında hak kazanmayı beklediği bedeli yansıtacak şekilde muhasebeleştirmeleri ve hasılatın istisnai türdeki uygulamalarının tanımlanmasına ve muhasebeleştirilmesine ve finansal tablo dipnotlarında gelir hakkında yatırımcıların daha iyi bilgilendirilmesine ilişkin detaylı hükümler içermesidir "(KGK, http://kgk.gov.tr, 2017).

TFRS 15'de hasılatın tanınması için işletmenin müşteri ile yaptı̆̆ı ssözleşmede belirtilen bir çok konu ile ilgili koşulun geç̧ekleşmesi gerekli iken, BOBİ FRS'de mal satışında, mal veya hizmetlerle takas işlemlerinde hasılatın kayda alınmasındaki kriterler TMS 18 paralelindedir. Buna göre mal satışına ilişkin hasılat, aşağıdaki ölçütlerin tümü sağlandığında kayda alınır( madde 5.14):

-Malların sahipliğinden kaynaklanan önemli risk ve getirilerin alıcıya devredilmiş olmast.

-Satılan mallar üzerinde bir kontrolün sürdürülmemesi. Bir varlığın kontrolü, varlı̆̆ın kullanımın yönetebilme ve varlı̆̆ın kalan tüm faydasını büyük ölçüde elde edebilme gücünü ifade eder. Kontrol, başka işletmelerin varliğın kullanımını yönetebilmesini ve ondan fayda elde etmesini engelleyebilme gücünü kapsamaktadır.

- Hasılat tutarının güvenilir biçimde ölçülebilmesi.

-Işleme ilişkin ekonomik faydaların işletmece elde edilmesinin muhtemel olmast.

-İsleme ilişkin katlanılan veya gerçekleşecek maliyetlerin güvenilir biçimde ölçülebilmesi.

Mal veya hizmetlerin benzer özelliklere ve değere sahip mal veya hizmetlerle takasında hasılat ortaya çıkmaz. Bununla birlikte, mal veya hizmetlerin, benzer özelliklere ve değere sahip olmayan mal veya hizmetlerle takası durumunda, hasılat kayda alınır. Bu durumda hasılat, alınan mal veya hizmetin gerçeğe uygun değeri esas alınarak ölçülür. Hasılatın ölçümünde, alınan mal veya hizmetin gerçeğe uygun değerine varsa ilgili işlemde alınan (veya ödenen) tutarlar eklenir (veya çıkartılır). Alınan mal veya hizmetin gerçeğe uygun değerinin güvenilir şekilde ölçülememesi durumunda elden çıkarılan mal veya hizmetin gerçeğe uygun değeri esas alınır. Elden çıkarılan mal veya hizmetin gerçeğe uygun değerinin de güvenilir şekilde ölçülememesi durumunda elden çıkarılan varlığın defter değeri esas alınır.(madde 5.12 )

Hizmet sunumuna ilişkin bir işlemin sonucunun güvenilir şekilde tahmin edilebildiği durumlarda, ilgili hasılat tutarı, işlemin raporlama dönemi sonu itibarıyla tamamlanma düzeyi dikkate alınarak kayda alınır. İşlemin tamamlanma düzeyi dikkate alınarak hasılatın kayda alınması "tamamlanma yüzdesi yöntemi" olarak adlandırılır. Bu yönteme göre hasılat, hizmetin sunulduğu dönemlerde finansal tablolara yansitılır(madde 5.18) Bu düzenleme TMS 
18 ve TMS 11 paralelindedir. Çünkü, TMS 18 ve TMS 11'deki tamamlanma yüzdesi yöntemi yerine TFRS 15'e göre, bir edim yükümlülügü, müşteriye taahhüt edilen mal veya hizmet transfer edilerek yerine getirildiğinde, bu edim yükümlülüğüne dağıtılmış olan işlem fiyatı tutarı, hasılat olarak muhasebeleştirilmektedir.

TMS 18 ile uyumlu olarak, BOBİ FRS madde 5.21'e göre, hizmet sunumuna ilişkin bir işlemin sonucunun güvenilir şekilde tahmin edilemediği durumlarda, geri kazanılması beklenen gider tutarı kadar hasılat kayda alınır. Bu durumda ilgili hizmet sunumuna ilişkin olarak herhangi bir kâr ortaya çıkmaz. Hizmet sunumuna ilişkin işlemin sonucunun güvenilir şekilde tahmin edilemediği ve giderlerin de geri kazanılmasının beklenmediği durumlarda ise hasılat kayda alınmaz, giderler kâr veya zarara yansıtılmaya devam edilir. BOBİ FRS'de "İnşa Sözleşmeleri” ve "Tamamlama Yüzdesi Yöntemi” başlı̆̆ı altında bu ilkeler doğrultusunda açıklamalar yapılmıştır.

BOBİ FRS'ye göre hasılat, taraflar arasında yapılan anlaşma kapsamında, satış iskontoları (kasa ve miktar iskontoları) da düşüldükten sonra, alınan veya alınması beklenen bedel esas alınarak ölçülür. Hasılatın tahsilatı geleceğe ötelenmişse, işlemin finansman niteliği taşıması durumunda, TMS 18 ve TFRS 15 ile uyumlu olarak faiz ayrıştırmasının yapılması gerekir. TMS 18'de faiz ayrıştırması için bir yıl esası yer almaz ancak bu konuda TFRS 15'deki kolaylaştırıcı yöntem esas alınmıştır ve BOBİ FRS'ye göre eğer hasılat bedelinin, bir yıl veya daha kısa sürede tahsil edilmesi öngörülüyorsa, hasılat, vade fark1 ayrıştırması yapılmaksızın doğrudan tahsil edilen veya edilmesi beklenen bedel üzerinden ölçülür. $\mathrm{Bu}$ bedelin, bir yıldan daha uzun bir vadede tahsil edilmesinin öngörülmesi durumunda ise hasılat, işlemdeki vade farkı ayrıştırılarak ilgili mal veya hizmetin peşin bedeli üzerinden ölçülür. "Finansal Araçlar ve Özkaynaklar” bölümünde belirtildiği gibi etkin faiz yöntemine göre hesaplanan vade farkı tutarı faiz geliri olarak muhasebeleştirilir(madde 5.8. ve 5.9) Burada peşin bedelin esas alınması TMS 18 ve TFRS 15 ile uyumludur ancak iskonto oranı ile ilgili bir düzenleme BOBİ FRS'de bulunmamaktadır. Ayrıca bir yıldan kısa vadeli satışlar için faiz ayrıştırmasının yapılmaması, sadece TFRS 15 madde 63 ile uyumludur. TFRS 15 madde 61'e göre önemli bir finansman bileşeni için taahhüt edilen bedelde düzeltme yapılmasının amacı, taahhüt edilen mal veya hizmetler devredildiğinde müşteri bu mal veya hizmetler için nakden ödeme yapmış olsaydı ödeyeceği fiyatı (nakit satış fiyatını) yansıtan bir tutar üzerinden hasılatın işletmenin finansal tablolarına alınmasını sağlamaktır. Ancak TFRS 15 madde 63'de kolaylaştırıcı bir uygulama olarak işletme, sözleşmenin başlangıcında, müşteriye taahhüt ettiği mal veya hizmetin devir tarihi ile müşterinin bu mal veya hizmetin bedelini ödediği tarih arasında geçen sürenin bir yıl veya daha az olacağını öngörmesi durumunda, taahhüt edilen bedelde önemli bir finansman bileşeninin etkisi için düzeltme yapmak zorunda değildir. 


\section{STOK VE SATIŞ MALIYETLERININN RAPORLANMASI}

BOBİ FRS Bölüm 6'da, olağan işletme faaliyetleri kapsamında satılmak üzere elde tutulan, üretilen ve üretim sürecinde veya hizmet sunumunda kullanılacak ham madde ve malzeme stoklarına ilişkin muhasebe ilkeleri düzenlenmektedir. TMS 2 ile uyumlu olarak stoklar, maliyet bedeli ile net gerçekleşebilir değerden düşük olanı üzerinden ölçülür(madde 6.4) Stokların değer düşüklüğüne uğraması durumunda, stokların defter değeri net gerçekleşebilir değerine indirilir. Bu indirim tutarı, değer düşüklüğü zararını oluşturur ve Kâr veya Zarar Tablosunda "Satışların Maliyeti” kalemine yansıtılır(madde 6.22)

Satın alınan stok maliyetinin belirlenmesinde TMS 2'den farklılaşan tek husus, vadeli alımlarda bir yıl veya daha kısa vadeli bir ödeme karşılığında satın alınan stokların, vade farkı ayrıştırılmaksızın, ödenen veya ödenmesi beklenen nakit tutar üzerinden ölçülmesidir. Bir yıldan uzun vadeli bir ödeme karşılığında satın alınan stoklar ise, vade farkı ayrıştırılarak peşin fiyat üzerinden (diğer bir ifadeyle işletme peşin ödeme yapmış olsaydı ödeyeceği fiyat üzerinden) ölçülür. $\mathrm{Bu}$ kapsamda bir stokun bir yıldan daha uzun vadeli bir ödeme karşılığında satın alınması durumunda vade farkı tutarı, etkin faiz yöntemine göre hesaplanarak, faiz gideri olarak muhasebeleştirilir( madde 6.8) Stoklara ilişkin borçlanma maliyetleri oluştukları dönemde kâr veya zarara yansıtılır. Ancak üretilmesi normal şartlar altında bir yıldan daha uzun süren stoklar için katlanılan borçlanma maliyetleri satışa hazır hale geldiği tarihe kadar stokun maliyetine dâhil edilir.(madde 6.9)

Mamul maliyetleri üretim giderlerinin gerçekleşmiş tutarları esas alınarak fiili maliyet yöntemine göre belirlenir. Ancak sonuçlar fiili maliyete yakınsa, standart maliyet yöntemi veya perakende yöntemi gibi stok maliyeti ölçüm yöntemleri kullanılabilir. Standart maliyet hesabında, ham madde ve malzemelerin, işçiliğin, verimliliğin ve kapasite kullanımının normal düzeyleri dikkate alınır. Standart maliyetler, düzenli olarak gözden geçirilir ve gerektiği takdirde mevcut şartlara göre yeniden belirlenir. Perakende yönteminde maliyet, stokların satış değerinden uygun brüt kâr marjının düşülmesi suretiyle bulunur.( madde 6.19) Stokların maliyeti, ilk giren ilk çıkar (FIFO) veya ağırlıklı ortalama maliyet yöntemlerinden biri kullanılarak hesaplanır(madde 6.20)

Bu bölümdeki düzenlemeler genel olarak TMS 2 ile uyumlu olmakla birlikte aşağıdaki farklılıklar bulunmaktadır.

- Vadeli alımlarda bir yıl veya daha kısa vadeli bir ödeme karşılığında satın alınan stokların, vade farkı ayrıştırılmaz.

-TMS 2'de normal maliyet önerilmesine rağmen BOBİ TFRS'de dönüştürme maliyetlerinin belirlenmesinde tam maliyet yöntemi kullanılır. Tam maliyet yönteminde, sabit ve değişken genel üretim giderlerinin tamamı dönüştürme maliyetine dâhil edilir. Ancak faaliyetleri geçici veya kalıcı olarak durdurulan ya da henüz faaliyete geçmemiş bölümlere ilişkin sabit genel üretim giderleri dönüştürme maliyetine dâhil edilmez, gider olarak 
“Satışların Maliyeti” kaleminde gösterilir. Ancak madde 6.13'e göre, TMS 2'de önerilen normal maliyet yöntemi de kullanılabilir. Her bir üretim birimine dağıtılan sabit genel üretim gider tutarı, düşük kapasite ya da atıl kapasite nedeniyle arttırılamaz. Dağıtılmayan genel üretim gideri, gerçekleştiği dönemde "Satışların Maliyeti” kaleminde gösterilir. Değer düşüklüğünün iptal edilecek kısmı, ilgili stokun maliyet bedeli esas alınarak belirlenir. Stokun, değer düşüklüğünden sonra belirlenen değeri, stokun maliyet bedelini aşamaz (madde 6.25) TMS 2 Madde 64'de yer alan "Net gerçekleşebilir değerin artışından dolayı iptal edilen stok değer düşüklüğü karşılık tutarı, iptalin gerçekleştiği dönemin tahakkuk eden satış maliyetini azaltacak şekilde muhasebeleştirilir.” hükmü BOBİ FRS'de yer almamaktadır. Bir başka deyişle TMS 2'deki uygulamanın tersine, BOBİ FRS'de karşılık iptalleri nedeniyle satışların maliyetinin azaltılması söz konusu değildir.

- BOBİ FRS madde 6.15'de sıralanan "Stok Maliyetine Dâhil Edilmeyen Giderler" TMS 2'de de aynıdır. Ancak TMS 2 madde 38'de, “Dönem içinde gider kaydedilen stokların tutarı, başka bir deyişle satılan malın maliyeti, satılan stokların ölçümünde stok maliyetine giren unsurlardan ve stok maliyetine dağttılmayıp doğrudan gider kaydedilen dağttılmamış genel üretim maliyetlerinden ve üretim maliyetleri ile ilgili fire ve kayıplar gibi anormal üretim giderleri tutarlarından oluşur. Işsletmeye özgü bazı özel durumlar da dă̆ıtım maliyetleri gibi başka tutarların da stok giderlerine dahil edilmesini gerektirebilir." şeklindeki bu ifade, BOBİ FRS Bölüm 6'da yer almamakta, stok maliyeti dişında satış maliyetinin artıracak şekilde ilaveten sadece, durdurulan ya da henüz faaliyete geçmemiş bölümlere ilişkin sabit genel üretim giderleri, normal maliyet yönteminin kullanılması halinde üretim maliyetlerine dağıtılmayan genel üretim gideri ve stok değer düşüklüğü karşılık giderlerinin raporlanacağını ifade etmektedir.

- Hizmet sağlayan işletmelerin stok maliyeti BOBİ FRS 6.17'de düzenlenmiştir. Buna göre, hizmet işletmeleri, eğer varsa stoklarını bunların üretimi için katlanılan maliyetler üzerinden ölçer. Bu maliyetler esas olarak, hizmetin sunulmasında doğrudan görev alan çalışanların ücret ve diğer maliyetleri ile hizmet sunumuyla ilişkilendirilebilen giderleri içerir. Satış ve genel yönetimle ilgili işçilik ücretleri ve diğer giderler, hizmetin maliyetine dâhil edilmez; bunlar gerçekleştikleri dönemde gider olarak kayda alınır. Bu düzenleme TMS 2 madde 19 ile uyumludur. Ancak TMS 2'ye göre finansal durum tablosunda "tamamlanmış hizmet maliyetleri" ve "tamamlanmamış hizmet maliyetleri" isimli stok hesaplarının yer alması önerilmekteyken, BOBİ FRS düzenlemelerinde ve finansal durum tablosu aktifinde benzer hesaplara yer verilmemiştir.

\section{MADDİ DURAN VARLIKLAR}

BOBİ FRS 12. bölümde maddi duran varlık tanımı TMS 16 ile uyumlu olarak verilmiş, yedek parça ve bakım malzemelerinin de, maddi duran varlık tanımını karşılaması durumunda bu bölüm kapsamında ele alınacağı, aksi taktirde stoklar içerisinde sınıflandırılacağı, edinimden sonra yapılan ve varlığın ekonomik ömrünü uzatarak veya 
kapasitesini genişleterek, gelecekte elde edilecek faydayı artıran harcamaların (yenileme harcamaları ve büyük çaplı kontroller için yapılan harcamalar gibi) varlığın defter değerine dâhil edileceği ifade edilmiştir.

Maddi duran varlıklar, ilk kayda almada maliyet bedeliyle ölçülür ve maliyet bedelinin tespiti TMS 16 ile uyumlu olmakla birlikte, vadeli alımlarda maliyetin tespitinde bazı farklılıklar bulunmaktadır. TMS 16'ya göre, eğer ödeme normal kredi vadelerinin ötesine erteleniyorsa, peşin fiyat eşdeğeri ile toplam ödeme arasındaki fark, (özellikli varlık olmadığ1 sürece) kredi dönemi boyunca faiz olarak finansal tablolara yansitılır. ( TMS 16 madde 23) BOBİ FRS'de ise, bir yıllık vade esas alınmıştır. Buna göre, "Bir yıl veya daha kısa vadeli bir ödeme karşılığında satın alınan maddi duran varlıklar, vade farkı ayrıştırılmaksızın, ödenen veya ödenmesi beklenen nakit tutar üzerinden ölçülür." Bir yıldan uzun vadeli bir ödeme karşılığında satın alınan maddi duran varlıklar ise, vade farkı ayrıştırılarak peşin fiyat üzerinden (diğer bir ifadeyle işletme peşin ödeme yapmış olsaydı ödeyeceği fiyat üzerinden) ölçülür, vade farkı tutarı, etkin faiz yöntemine göre hesaplanan faiz gideri olarak muhasebeleştirilir. ( madde 12.9) TMS 16'da olduğu gibi, maddi duran varlıklara ilişkin borçlanma maliyetleri (inşası bir yıldan daha uzun süren maddi duran varlıklar hariç) oluştukları dönemde kâr veya zarara yansıtılır.

Takas yoluyla edinimde elde edilen maddi duran varlığın değeri,, TMS 16'ya göre işlemin ticari içeriği varsa ve gerçeğe uygun değeri tespit edilebiliyorsa, elde edilen varlığın veya elden çıkarılan varlığın gerçeğe uygun değeri ile ölçülür. Eğer gerçeğe uygun değeri tespit edilemiyorsa, elden çıkarılan varlığın defter değeri ile ölçülür. BOBİ FRS madde 12'ye göre ise, takas yoluyla edinilen maddi duran varlığın veya varlıkların maliyeti, elden çıkarılan parasal olmayan kalemin net defter değeri esas alınarak belirlenir. Takasta parasal bir kalem de alınmış veya verilmiş ise, elden çıkarılan parasal olmayan kalemin net defter değerine, ödenen parasal kalemin gerçeğe uygun değeri eklenir ya da elden çıkarılacak parasal olmayan kalemin net defter değerinden, alınan parasal kalemin gerçeğe uygun değeri indirilir.

BOBİ FRS'ye göre maddi duran varlıkların sonraki ölçümlerinde, birikmiş amortisman ve birikmiş değer düşüklüğü zararları indirilmek suretiyle belirlenen maliyet değeri yada yeniden değerlenmiş tutarı kullanılabilir. Yeniden değerlenmiş tutar, değerlemenin yapıldığı tarihteki gerçeğe uygun değerinden, yeniden değerlemenin yapıldığ tarihten sonraki birikmiş amortisman tutarı ve birikmiş değer düşüklüğü zararı indirilerek hesaplanır. Finansal Durum Tablosunda özkaynaklarda "Yeniden Değerleme Yedeği" kaleminde gösterilir. Ancak, bu artış, aynı varlığın daha önce kâr veya zarara yansıtılan yeniden değerleme değer azalışını tersine çevirdiği ölçüde kâr veya zararda gösterilir. Bir maddi duran varlığın defter değerinin yeniden değerleme sonucunda azalması durumunda, bu azalışın aynı varlık için yeniden değerleme yedeğinde yer alan tutar kadarlık kısmı yeniden değerleme yedeğinden indirilir. Ancak yeniden değerleme azalışının yeniden değerleme yedeğinde yer alan tutardan yüksek olması durumunda aradaki fark kâr veya zarara yansıtılır. 
Bir maddi duran varlık finansal tablo dışı bırakıldığında bu varlığa ilişkin olarak yeniden değerleme yedeğinde yer alan birikmiş tutar "Geçmiş Yıllar Kârları/Zararları” kalemine aktarılır. Bu düzenlemeler TMS 16 ile aynı paraleldedir.

Tam set standartlarda gerçeğe uygun değer tespiti ile ilgili TFRS 13 kapsamında ayrıntılı düzenlemeler bulunmasına karşılık, BOBİ FRS madde 12.7'de yeniden değerleme tarihindeki gerçeğe uygun değerin, kamu kurumlarınca yetkilendirilmiş kişiler tarafından yada gerekli mesleki bilgiye sahip ve maddi duran varlığın sınıf ve yeri hakkında güncel bilgisi bulunan kişiler tarafından yapılabileceği ve değerlemelerin kim tarafından yapıldığının dipnotlarda açıklanması gerektiği belirtilmektedir.

Her bir raporlama dönemi sonunda varlık kalemlerinde değer düşüklüğü olup olmadığının ve varsa değer düşüklügü zararının nasıl ölçülüp muhasebeleştirileceğinin belirlenmesi için BOBİ FRS “18. Varlıklarda Değer Düşüklüğ̈̈” bölümünde belirtilen hükümler uygulanır. BOBİ FRS madde 18.27 'e göre, maliyet bedeliyle ölçülen varlıklara ilişkin değer düşüklüğü zararları kâr veya zarara yansıtılır. Ancak yeniden değerlenmiş tutarı üzerinden ölçülen maddi duran varlıklara ilişkin değer düşüklüğü zararları "Maddi Duran Varlıklar" bölümüne göre yeniden değerleme değer azalışı olarak dikkate alınır. Kâr veya zarara yansıtılan değer düşüklüğü zararları Kâr veya Zarar Tablosunda varlığın kullanıldığı işletme fonksiyonuna ilişkin giderlerin yansıtıldığı kalemde gösterilir. Örneğin, pazarlama bölümüyle ilgili olarak kullanılan varlığa ilişkin değer düşüklüğü zararı "Pazarlama Giderleri" kaleminde, üretim bölümüyle ilgili kullanılan varlıklara ilişkin değer düşüklüğü zararı ise "Satışların Maliyeti” kaleminde gösterilir.

Varlığın geri kazanılabilir tutarının defter değerini aşması durumunda ilgili varlığa ilişkin değer düşüklüğü zararının tamamı ya da bir kısmı iptal edilir. Değer düşüklüğü zararının iptal edilecek kısmı, ilgili varlığa ilişkin önceki dönemlerde değer düşüklüğü zararı kayda alınmamış olsaydı varlığın ulaşacağı (amortisman veya itfa payı çıkarılmış olarak) defter değeri esas alınarak belirlenir. Değer düşüklüğü zararının iptalinden sonra varlığın yeni defter değeri bu değeri aşamaz.( madde 18.34) İptal edilecek değer düşüklüğü zararı; bireysel olarak değer düşüklüğü testine tabi tutulan ve maliyet bedeli ile ölçülen varlıklarda kâr veya zarara yansitılarak Kâr veya Zarar Tablosunun ilgili kaleminde gösterilirken, yeniden değerlenmiş tutarı üzerinden ölçülen maddi duran varlıklarda "Maddi Duran Varlıklar" bölümüne göre yeniden değerleme değer artışı olarak dikkate alınır.

Amortisman uygulamalarında, TMS 16 ile uyumlu olmak üzere, varlık kullanıma hazır olduğunda başlanır ve kullanılan gün esasına göre kıst amortisman hesaplanır. Amortismana tâbi tutar, maddi duran varlığın maliyet bedelinden ya da yeniden değerleme sonrası bulunan tutarından kalıntı değerin indirilmesi suretiyle belirlenir. Amortisman yöntemi, varlığın gelecekteki ekonomik faydasının işletme tarafından öngörülen tüketim şeklini yansıtacak şekilde tespit edilir. Doğrusal yöntem, azalan bakiyeler yöntemi ve üretim miktarı yöntemleri gibi yöntemler kullanılabilir. Amortisman ayırma işlemine, varlık atıl 
bırakıldığında ya da kullanımdan kaldırıldığında da devam edilir. Varlığın kalıntı değeri ve faydalı ömrü değişirse, bu değişiklikler "Muhasebe Politikaları, Tahminler ve Yanlışlıklar" bölümü uyarınca muhasebe tahminlerindeki değişiklikler olarak nitelendirilir. Eğer bir varlıkta değer düşüklüğü göstergeleri varsa, değer düşüklügü zararı kayda alınmayacak olsa bile, söz konusu varlığın geri kalan faydalı ömrünün, amortisman veya itfa yönteminin ve kalıntı değerinin gözden geçirilmesi gerekebilir.

Amortisman veya itfa payı gelecekteki dönemlerde, değer düşüklüğü veya değer artışının kaydından sonraki varlığın yeni defter değeri esas alınarak hesaplanır.

\section{MADDİ OLMAYAN DURAN VARLIKLAR}

Maddi olmayan duran varlıklar BOBİ FRS 14. bölümde ele alınmış ve TMS 38 paralelinde tanımlanmıştır. Bu bölüm iş birleşmeleri sonucu ortaya çıkan şerefiyeye ve işletmenin olağan faaliyetleri kapsamında satış amacıyla elde tuttuğu maddi olmayan duran varlıklara uygulanmaz. İş birleşmesinde ortaya çıkan şerefiyenin kayda alınma ve ölçüm hükümleri "İşs Birleşmeleri” bölümünde ele alınmıştır. İşletmenin olağan faaliyetleri kapsamında satış amacıyla elde tuttuğu maddi olmayan duran varlıklar "Stoklar" bölümü uyarınca kayda alınır ve ölçülür. Madenler üzerindeki haklar ve maden kaynakları bu bölüm kapsamında maddi olmayan duran varlık olarak değerlendirilmez. Bir varlık maddi ve maddi olmayan unsurları birlikte içerebilir. Bu durumda varlık için hangi unsurun daha önemli olduğuna karar verilerek ilgili varlık maddi duran varlık ya da maddi olmayan duran varlık olarak kayda alınır.

Şerefiye ile ilgili düzenlemeler BOBİ FRS 21. bölümde yer almaktadır ve buna göre, edinen işletme birleşme tarihinde iş birleşmesinde ortaya çıkan şerefiyeyi varlık olarak kayda alır. Şerefiye tutarı; birleşme tarihinde, iş birleşmesinin maliyetinin, edinilen tarafin bu bölüme göre kayda alınan ve ölçülen net varlıklarındaki edinen işletmenin payını aşan kısmıdır. Tam set standartlara göre şerefiye için amortisman uygulanmayıp, değer düşüklüğü testi uygulanması gerektiği halde, BOBİ FRS'de şerefiye amortismana tabi tutulur. Şerefiye sonraki dönemlerde, ilk kayda alındığı tutardan birikmiş itfa payları düşülerek ölçülür. Şerefiyeye ilişkin itfa payının hesaplanmasında "Maddi Olmayan Duran Varlıklar" bölümünün "İtfa" başlıklı kısmında yer alan hükümler uygulanır. Şerefiyenin faydalı ömrünün güvenilir bir şekilde tahmin edilemediği durumlarda şerefiye 10 yılda itfa edilir. Şerefiye değer düşüklüğü testine tâbi tutulmaz.

Maddi olmayan duran varlıklar, ilk kayda almada maliyet bedeliyle ölçülür ve maliyet bedelinin tespiti maddi duran varlıklardaki gibidir. Bir yıl veya daha kısa vadeli bir ödeme karşılığında satın alınan maddi olmayan duran varlıklar, vade farkı ayrıştırılmaksızın, ödenen veya ödenmesi beklenen nakit tutar üzerinden ölçülür. Bir y1ldan uzun vadeli bir ödeme karşılığında satın alınan maddi olmayan duran varlıklar ise, vade farkı ayrıştırılarak peşin fiyat üzerinden (diğer bir ifadeyle işletme peşin ödeme yapmış olsaydı ödeyeceği fiyat 
üzerinden) ölçülür, vade farkı tutarı, etkin faiz yöntemine göre hesaplanan faiz gideri olarak muhasebeleştirilir. Borçlanma maliyetleri ve takas ile edinilen maddi olmayan duran varlıklardaki uygulamalar, maddi duran varlıklardaki gibidir. Maddi olmayan duran varlığın iş birleşmesi kapsamında edinilmiş olması durumunda maliyet bedeli, "İş Birleşmeleri" bölümüne göre edinim tarihinde belirlenen değeridir.

Tam set standartlar ile uyumlu olarak, işletmede oluşturulan şerefiye ile maddi olmayan unsurlar için katlanılan ve maddi olmayan duran varlık tanımını karşılamayan harcamalar, BOBİ FRS uyarınca, diğer bir varlık maliyetinin bir parçası olmadığı sürece maddi olmayan duran varlık olarak aktifleştirilmez; bu harcamalar oluştukları dönemde gider olarak kâr veya zarara yansitılır. Aşağıdakilere ilişkin harcamalar bu kapsamda değerlendirilir: (madde 14.14)

a) İşletmede oluşturulan şerefiye,

b) İşletmede oluşturulan markalar, logolar, yayın hakları, müşteri listeleri ve özü itibarıyla bunlara benzer nitelikteki kalemler.

c) Kuruluş ve örgütlenme giderleri.

ç) Eğitim harcamaları,

d) Reklam ve tanitım harcamaları,

e) Bir işletmenin kısmen veya tamamen yerinin değiştirilmesi veya yeniden yapılandirılması sirasında katlanılan harcamalar.

Araştırma safhasında yapılan harcamalar aktifleştirilmez, gerçekleştiğinde gider olarak kâr veya zarara yansıtılır. Geliştirme; ticari üretime ya da kullanıma başlanmadan önce, araştırma sonuçlarının ya da diğer bilgilerin, yeni veya önemli ölçüde geliştirilmiş malzeme, cihaz, ürün, süreç, sistem ya da hizmetlerin üretiminin planlanmasında veya tasarımında uygulanmasıdır ve madde 14.17 'deki şartları sağlayan geliştirme harcamaları maddi olmayan duran varlık olarak aktifleştirilir ve bu şartların sağlandığ 1 tarihten itibaren katlanılan harcamalar işletmede oluşturulan maddi olmayan duran varlığın maliyetini oluşturur. Daha önce gider olarak kayda alınan harcamalar sonradan ilgili varlığın maliyetine dâhil edilemez.

Bir maddi olmayan duran varlığın oluşturulmasına yönelik işletme içi bir projenin araştırma safhasıyla geliştirme safhasının ayırt edilememesi durumunda, harcamalar araştırma safhasında yapılmış gibi dikkate alınır. Bir maddi olmayan duran varlıktan gelecekte elde edilecek faydayı arttıran ve varlıkla doğrudan ilişkisi kurulabilen harcamalar, ilgili varlığın defter değerine dâhil edilir.

Sonraki ölçümlerde, maddi olmayan duran varlıklar, ilk kayda almadan sonra birikmiş itfa payları ve birikmiş değer düşüklügü zararları düşülmek suretiyle maliyeti üzerinden ölçülür. BOBİ FRS bölüm 12'de maddi duran varlıklarda, TMS 16 ve TMS 38'de maddi/maddi olmayan duran varlıklarda kullanılan yeniden değerleme yöntemi, BOBİ FRS 
bölüm 14'e göre maddi olmayan duran varlıklarda kullanılmamaktadır. BOBİ FRS'de maddi olmayan duran varlıklar için sadece maliyet yönteminin kullanılması esas alınmıştır. Buna göre, maliyet değeri ile değerlenen duran varlıklardaki gibi değer düşüklüğü tespit edildiğinde değer azalışı gider olarak kaydedilir ve değer düşüklüğü zararının iptalinde, önceki gider kaydı tutarı kadar gelir kaydı yapılır.

Maddi olmayan duran varlıklar için kalıntı değerin tespiti, amortisman yönteminin seçimi, kıst amortisman uygulanması ve itfa giderlerinin kaydı ile ilgili uygulamalar maddi duran varlıklardaki gibidir. Ancak faydalı ömür ile ilgili maddi olmayan duran varlıklara özgü düzenlemeler bulunmaktadır. Buna göre sözleşmeden doğan haklardan veya diğer yasal haklardan kaynaklanan bir maddi olmayan duran varlığın faydalı ömrü, sözleşmeden doğan hakların veya diğer yasal hakların geçerlilik süresini aşamaz; ancak işletmenin varlı̆̆ı kullanmayı öngördüğü süreye bağlı olarak bu sürelerden daha kısa olabilir. Sözleşmeden doğan hakların veya diğer yasal hakların, sınırlı bir zaman dilimi için (sözleşme yenilenerek bu zaman dilimi uzatılabilir) devralınmış olması durumunda, sadece, işletmenin sözleşmeyi yenileme işlemini, önemli maliyetlere katlanmadan yapacağına dair kanıt bulunduğu takdirde, söz konusu yenileme dönemi (dönemleri) ilgili maddi olmayan duran varlığın faydalı ömrüne dâhil edilir. Faydalı ömrü sınırlı olan maddi olmayan duran varlıklar için itfa payı ayrılması zorunludur. Bu düzenlemeler TMS 38 ile uyumludur.

Ancak TMS 38'den farklı olarak, BOBİ FRS madde 14.33'e göre, faydalı ömrü belirsiz olan maddi olmayan duran varlıklar, 5 ylldan az 10 yıldan çok olmayacak şekilde, işletme tarafından belirlenen sürede itfa edilir. Oysa TMS 38'de faydalı ömrü belirsiz olan maddi olmayan duran varlıkların değer düşüklüğü testine tabi tutulması gerekmektedir.

Faydalı ömrü belirsiz olduğu değerlendirilen maddi olmayan duran varlıkların faydalı ömürleri, her yıl gözden geçirilir. Daha önce faydalı ömrünün belirsiz olduğu tespit edilen bir maddi olmayan duran varlığın faydalı ömrü belirlenebildiğinde bu durum "Muhasebe Politikaları, Tahminler ve Yanlışlıklar" bölümü uyarınca muhasebe tahminlerindeki değişiklikler olarak nitelendirilir.( madde 14.34)

\section{VARLIKLARDA DEĞER DÜŞÜKLÜĞÜ}

TMS 36 ile uyumlu olan BOBİ FRS 18. bölümde varlıklarda değer düşüklüguüne ilişkin düzenlemeler yer almaktadır. Buna göre, her raporlama dönemi sonunda varlığın değer düşüklüğüne uğradığına ilişkin bir göstergenin ${ }^{1}$ mevcut olup olmadığı değerlendirilir. Bu tür bir gösterge varsa, varlığın geri kazanılabilir tutarı belirlenir. TMS 36 'da olduğu gibi geri kazanılabilir tutar, varlığın (veya nakit yaratan birimin) satış maliyetleri düşülmüş gerçeğe uygun değeri ile kullanım değerinden yüksek olanıdır. Geri kazanılabilir tutar, her bir varlık için ayrı ayrı belirlenir. Ancak bir varlı̆̆ın geri kazanılabilir tutarının ayrı olarak

\footnotetext{
${ }^{1}$ Değer düşüklüğü göstergeleri BOBİ FRS madde 18.5 'de sıralanmaktadır.
} 
belirlenemediği durumlarda, varlı̆̆ın ait olduğu nakit yaratan birimin geri kazanılabilir tutarı hesaplanır.

Elden çıkarmak üzere elde tutulan varlıklar için ve varlığın kullanım değerinin önemli ölçüde daha yüksek olmaması halinde, varlığın satış maliyetleri ${ }^{2}$ düşülmüş gerçeğe uygun değeri, geri kazanılabilir tutar olarak kullanılabilir. Bu değer, bir varlığın, bilgili ve istekli taraflar arasında karşılıklı pazarlık ortamında piyasa şartları çerçevesindeki satış tutarından, elden çıkarma maliyetleri indirildikten sonra elde edilebilecek tutardır. Madde 18.13'e göre, eğer varlığa ilişkin bir satış anlaşması veya varlığın faal bir piyasası yoksa, satış maliyetleri düşülmüş gerçeğe uygun değer, aynı sektördeki benzer varlıklara ilişkin yakın geçmişte yapılan işlemlerin sonuçları dikkate alınarak raporlama tarihi itibarıyla, elden çıkarma maliyetleri de düşüldükten sonra, bilgili ve istekli taraflar arasında karşılıklı pazarlık ortamında yapılacak bir satıştan sonra elde edilebilecek tutarı yansıtan en gerçekçi bilgiye dayanmak suretiyle ölçülür.

Kullanım değeri bir varlıktan elde edilmesi beklenen gelecekteki nakit akışlarının bugünkü değeridir.(madde 18.15) BOBİ FRS madde 18.20, nakit akışlarının tahmin edilmesi için yol gösterici düzenlemeler içermektedir. Bugünkü değerin hesaplanmasında kullanılan iskonto oranı, risksiz cari piyasa faiz oranı ve varlı̆̆a özgü riskler gibi piyasa değerlendirmelerini yansıtan vergi öncesi orandır.(madde 18.22)

Kullanım değerinin hesaplanmasında aşağıdaki unsurlar dikkate alınır: (madde18.16)

a) İşletmenin varlıktan elde etmeyi beklediği gelecekteki nakit akışları,

b) Söz konusu nakit akışlarının tutarında veya zamanlamasında beklenen muhtemel sapmalar,

c) Paranın zaman değeri (risksiz cari piyasa faiz oranı üzerinden gösterilen),

ç) Varlığa özgü belirsizliklere katlanmanın bedeli,

d) Piyasa katılımcılarının, işletmenin varlıktan elde etmeyi beklediği gelecekteki nakit akışlarının fiyatlandırmasına yansıtacağı diğer unsurlar (örneğin varlığın likiditesinin azalmasi)

Bir varlığın( veya nakit yaratan birimin) satış maliyetleri düşülmüş gerçeğe uygun değeri defter değerinden yüksekse ya da kullanım değerinin satış maliyetleri düşülmüş gerçeğe uygun değerini önemli ölçüde aşmayacağı değerlendiriliyorsa (her iki tutarı da belirlemek her zaman gerekli değildir) varlı̆̆ın ait olduğu nakit yaratan birimin geri kazanılabilir tutarı hesaplanmaz.(madde 18.8) Bir nakit yaratan birimin defter değeri;

a) Nakit yaratan birimle doğrudan ilişkilendirilebilen veya mantıklı ve tutarlı bir şekilde söz konusu birime dağıtılabilen ve

\footnotetext{
${ }^{2}$ Madde 18.14'e göre, satış maliyetlerine yasal olarak ödenmesi gereken işlem vergileri ve benzeri diğer ödemeler, varlığı taşıma maliyetleri, varlığın tâbi olduğu bir kısıtlamanın kaldırılması amacıyla katlanılan maliyetler ve varlığı satışa hazır hale getirmek için katlanılan ilave maliyetler örnek olarak gösterilebilir.
} 
b) Nakit yaratan birimin kullanım değerinin belirlenmesi sırasında dikkate alınan gelecekteki nakit girişlerini oluşturan, varlıkların defter değerlerini içerir.(madde 18.24)

Tam set standartlardan farklı olarak BOBİ FRS'ye göre şerefiye değer düşüklüğü testine tâbi tutulmaz. Herhangi bir şerefiye tutarı nakit yaratan birimin defter değerinin hesabında dikkate alınmaz. Dolayısıyla bir varlığa ilişkin değer düşüklüğünün, bu varlığın ait olduğu nakit yaratan birimin geri kazanılabilir tutarı hesaplanarak tespit edildiği durumlarda, söz konusu nakit yaratan birimle ilişkilendirilebilen ya da bu birime dağıtılabilen bir şerefiye tutarı söz konusu olsa da ilgili nakit yaratan birimin defter değerine ilgili şerefiye tutarı dâhil edilmez. Nakit yaratan birim, şerefiye tutarı dâhil edilmemiş defter değeri ile geri kazanılabilir tutarı karşılaştırılarak değer düşüklüğü testine tâbi tutulur. Ayrıca nakit yaratan birimin defter değeri kayda alınan herhangi bir yükümlülüğün defter değerini içermez (geri kazanılabilir tutarın kayda alınan bir yükümlülük dikkate alınmadan belirlenemediği durumlar hariç)(madde 18.23,24,25).

Nakit yaratan birim için değer düşüklüğü zararı, nakit yaratan birime ait varlıkların (şerefiye dışındaki) defter değeriyle orantılı olarak ilgili varlıklara dağıtılır. Değer düşüklüğü zararı, varlı̆̆ın kullanıldı̆̆ işletme fonksiyonuna ilişkin giderlerin yansıııldığı kalemde gider olarak kayda alınarak Kâr veya Zarar Tablosunda gösterilir. Örneğin, pazarlama bölümüyle ilgili olarak kullanılan varlığa ilişkin değer düşüklüğü zararı "Pazarlama Giderleri" kaleminde, üretim bölümüyle ilgili kullanılan varlıklara ilişkin değer düşüklüğü zararı ise "Satışların Maliyeti" kaleminde gösterilir. Ancak, nakit yaratan birimdeki varlıkların defter değerleri, Satış maliyetleri düşülmüş gerçeğe uygun değerden, kullanım değerinden veya sıfirdan ( hangisi büyükse o esas alınır) az olamaz: (madde 18.29) Bu nedenle bir varlığa dağııılamayan değer düşüklüğü zararı tutarı, birimin diğer varlıklarına, söz konusu varlıkların defter değerleri ile orantılı olarak dağıtılır. Amortisman veya itfa payı gelecekteki dönemlerde, değer düşüklüğü zararının muhasebeleştirilmesinden sonra varlı̆ğın yeni defter değeri esas alınarak hesaplanır.

Nakit yaratan birimin geri kazanılabilir tutarının defter değerinden yüksek olması durumunda nakit yaratan birim için değer düşüklüğü zararı iptal edilir. İptal edilecek değer düşüklüğü zararlanı, nakit yaratan birime ait varlıkların (şerefiye dışındaki) defter değerleri ile orantılı olarak ilgili varlıklara dağı̆tlır. İptal edilecek değer düşüklüğü zararı; bireysel olarak değer düşüklüğü testine tabi tutulan ve maliyet bedeli ile ölçülen varlıklarda kâr veya zarara yansitılarak Kâr veya Zarar Tablosunun ilgili kaleminde gösterilirken, yeniden değerlenmiş tutarı üzerinden ölçülen maddi duran varlıklarda "Maddi Duran Varlıklar" bölümüne göre yeniden değerleme değer artı̧̧ olarak dikkate alınır.

\section{YATIRIM AMAÇLI GAYRIMENKULLER}

BOBİ FRS 13. bölümde ele alınan yatıım amaçlı gayrimenkullerin tanımı ve ilgili düzenlemeler TMS 40 ile uyumludur. Kira geliri veya değer artış kazancı ya da her ikisini 
birden elde etmek üzere elde tutulan, işletmenin sahip olduğu diğer varlıklardan büyük ölçüde bağımsız nakit akışı yaratan varlıklar, yatırım amaçlı gayrimenkul olarak nitelendirilir ve bu tür gayrimenkuller, işletmenin mülkiyetinde olan varlıklar olabileceği gibi, kiracı tarafından finansal kiralama yoluyla elde tutulan varlıklar da olabilir. ( madde 13.2) Ayrica geleneksel kiralama ( faaliyet kiralaması) yoluyla elde tutulan bir gayrimenkulün yatırım amaçlı gayrimenkul tanımını karşılaması durumunda, bu gayrimenkullere ilişkin haklar, yatırım amaçlı gayrimenkul olarak sınıflandırılabilir. Bu durumda bu gayrimenkullere ilişkin haklar ilk kez kayda alınırken, "Kiralamalar" bölümündeki geleneksel kiralamaya ilişkin hükümler yerine finansal kiralamaya ilişkin hükümler uygulanır. Bu hakların sonraki ölçümü ise bu bölüm uyarınca yapılır. Bu durumda, gerek ilk kayda almada gerekse sonraki ölçümlerde değerlemesi yapılacak unsur, sözleşmeye konu gayrimenkulün kendisi değil bu gayrimenkul üzerinde tesis edilen haktır.(madde 13.6)

İşletme tarafindan yatırım amaçlı olarak kullanılmak üzere inşa edilmekte veya geliştirilmekte olan gayrimenkuller de 13. bölüme göre değerlendirilir. Bir gayrimenkulün bir bölümü yatırım amacıyla elde tutulurken diğer bölümü de işletme faaliyetlerinde kullanılmak amacıyla elde tutulabilir. Yatırım amaçlı gayrimenkul olarak kullanılacak bölümün gerçeğe uygun değeri aşırı maliyet veya çabaya katlanılmadan ölçülemiyorsa gayrimenkulün tamamı "Maddi Duran Varlıklar" bölümü uyarınca maddi duran varlık olarak değerlendirilir.

Yatırım amaçlı gayrimenkuller (mevcut gayrimenkullerin sınıf değiştirdiği durumlar hariç) ilk kayda almada "Maddi Duran Varlıklar” bölümünün ilk kayıt hükümleri uygulanarak maliyet bedeliyle ölçülür. Bununla birlikte finansal kiralama yoluyla elde tutulan yatırım amaçlı gayrimenkullerin ilk kayda alma sırasındaki değeri, kiracı tarafından finansal kiralamaların ilk ölçümüne ilişkin "Kiralamalar" bölümündeki hükümler uygulanarak belirlenir.(madde 13.5)

Yatırım amaçlı gayrimenkuller, ilk kayda almadan sonra gerçeğe uygun değer yöntemi ya da maliyet yöntemi uygulanarak ölçülebilir. Gerçeğe uygun değer yönteminin uygulanması durumunda daha sonra muhasebe politikasında bir değişikliğe gidilerek yatırım amaçlı gayrimenkuller maliyet yöntemiyle ölçülemez. Ancak, gerçeğe uygun değer yöntemi seçilmiş olsa da yatırım amaçlı gayrimenkullerden gerçeğe uygun değeri aşırı maliyet veya çabaya katlanmadan ölçülemeyenler maliyet bedeliyle ölçülür. Bu durumda ilgili gayrimenkulün ölçümünde "Maddi Duran Varlıklar" bölümünde yer alan maliyet - amortisman - değer düşüklüğü yöntemi kullanılır. Gerçeğe uygun değerlerinin aşırı maliyet veya çabaya katlanmadan ölçülebilir hale gelmesi durumunda, bu gayrimenkuller, gerçeğe uygun değeri üzerinden ölçülmeye başlanır ve tespit edilen gerçeğe uygun değeriyle, önceki defter değeri arasındaki fark "Yatırım Amaçı Gayrimenkuller Değer Artış ve Satış Kazançları" veya "Yatırım Amaçlı Gayrimenkuller Değer Azalış ve Satış Zararları" kaleminde kâr veya zarara yansitilir. 
BOBİ FRS'ye göre, maliyet bedeli üzerinden ölçülen yatırım amaçlı gayrimenkullere ilişkin amortisman giderleri ve değer düşüklüğü zararı, "Diğer Faaliyetlerden Giderler" altında "Yatırım Amaçlı Gayrimenkuller Değer Azalış ve Satış Zararları" kaleminde gösterilir.(madde 18.27)

Yatırım amaçlı gayrimenkullerin elde tutulma amacının farklılaşması durumunda yeni elde tutulma amacina uygun olarak, bu varlıklar maddi duran varlıklara ya da stoklara aktarılır. Bu durumda, gayrimenkulün sınıf değişikliği tarihindeki değeri bu bölüme göre tespit edilir ve bu değeriyle ilgili varlık gruplarına aktarılır. Öte yandan bir maddi duran varlığın yatırım amaçlı gayrimenkullere aktarılması durumunda ise, varlığın sınıf değişikliği tarihindeki gerçeğe uygun değeriyle defter değeri arasındaki fark "Maddi Duran Varlıklar" bölümüne göre yeniden değerleme artışı ya da yeniden değerleme azalışı olarak dikkate alınır. Söz konusu yatırım amaçlı gayrimenkul finansal tablo dışı bırakıldığında bu varlığa ilişkin olarak yeniden değerleme yedeğinde yer alan birikmiş tutar "Geçmiş Yıllar Kârları/ Zararları" kalemine aktarılır. Yatırım amaçlı gayrimenkulün finansal tablo dışı bırakılmasından doğan kazanç ya da kayıp, kâr veya zarara yansıtılır.

\section{SONUÇ VE ÖNERILER}

Bu çalışmada, BOBİ FRS kapsamında yer alan, bazı özellikli sektörler ve durumlar için kullanılanlar hariç, tüm işletmelerin kullanacağı standartlar seçilerek temel konularda, tam set standartlar ile karşılaştırma yapılmış ve bunların büyük ölçüde tam set standartlar ile uyumlu olduğu tespit edilmiştir. Ancak, BOBİ FRS kapsamına alınmayan standartlar ve tam set standartlarda kıyasla yapılan sadeleştirmeler nedeniyle finansal durum tablosu ve kar zarar tablosu formatında değişiklikler ortaya çıkmaktadır. BOBİ FRS'de büyük işletmeler tarafindan finansal tablo kalemlerinin ölçümünde gerçeğe uygun değer kavramı kullanılmaktadır, ancak kapsamlı kar kavramı kullanılmamakta, buna ilişkin kalemler tablolarda yer almamaktadir.

BOBİ FRS, ülkemizde ticari karın tespiti için tam set standartlara kıyasla daha sade ve kolay uygulanabilecek bir standart getirdiğinden, tam set standartların da daha net anlaşılması ve doğru uygulanmasına katkı sağlayacak ve ülkemizdeki yerleşik vergi için muhasebe anlayışından, bilgi için muhasebe anlayışına geçişte önemli bir adım oluşturacaktır. Böylece muhasebenin temel görevi olan, gerçek faaliyet sonuçlarının raporlanması, gerçek durum tespiti, planlama ve denetim için kullanılabilir bilgiler üretmesi mümkün hale gelecek, ticari amaçlarla finansal verilerin kullanılması alışkanlığı yerleşecektir.

Tekdüzen muhasebe sistemini ve hesap planını kullanmaya alışkın olan ülkemiz için, tam set TMS/TFRS gereklerine göre bu hesap planının ve finansal tablo formatlarının güncellenmesi, bu formatların BOBİ FRS için gerekli olan kalemler kapsamında kullanılması, finansal durum tablosunda, stoklar, maddi duran varlıklar ve maddi olmayan duran varlıklar, diğer alacak ve borçların daha detaylı verilmesi, hem tabloların daha ayrıntılı bir rehber 
olmasını sağlayacak hem de ülkede tek tip finansal tablo uygulamalarını yaygınlaştıracaktır. Ayrıca denetime tabi olmayan işletmeler ve küçük işletmeler tarafindan da bazı muafiyetler ile BOBİ FRS kullanımının teşvik edilmesi tek tip finansal raporlama sağlayacaktır. $\mathrm{Bu}$ yönde ülkemizde yapılacak çalışmalar, muhasebe eğitimi ve uygulamalarının kolaylaştırılması, ticari kar kavramının yaygınlaşması açısından büyük önem taşımaktadır. Türkiye ekonomisi içinde yer alan işletmelerin küresel rekabetin gereklerini uygulayabilmesi için zorunlu olan bu adımlar, ülke ekonomisinin de güçlenmesini sağlayacaktır.

\section{KAYNAKLAR}

Kamu Gözetimi, Muhasebe ve Denetim Standartları Kurumu,_Büyük Ve Orta Boy İşletmeler İçin Finansal Raporlama Standardı Hakkında Tebliğg, 29 Temmuz 2017 tarihli ve 30138 (Mükerrer) sayılı Resmi Gazete

TMS 1 "Finansal Tabloların Sunuluşu", 16/01/2005 tarihli ve 25702 sayılı Resmi Gazete, (17. Güncelleme: 09/04/2015 tarihli ve 29321 say1lı Resmi Gazete).

TMS 2 Stoklar, 15/01/2005 tarih ve 25701 say1lı Resmi Gazete ( 7. Güncelleme 30/12/2012 tarih ve 28513 say1l Resmi Gazete)

TMS 8 Muhasebe Politikaları, Muhasebe Tahminlerinde Değişiklikler ve Hatalar , 20/10/2005 tarih ve 25972 sayılı Resmi Gazete ( 7. Güncelleme 30/12/2012 tarih ve 28513 sayılı Resmi Gazete)

TMS 10 Raporlama Döneminden (Bilanço Tarihinden) Sonraki Olaylar, 20/10/2005 tarih ve 25972 sayılı Resmi Gazete (4. Güncelleme 28/11/2008 tarih ve 27068 sayılı Resmi Gazete)

TMS 12 Gelir Vergileri, 28/03/2006 tarihli ve 26122 sayılı Resmi Gazete ( 13. güncelleme 05/03/2014 tarih ve 28932 sayılı Resmi Gazete

TMS 16 Maddi Duran Varlıklar, 31/12/2005 tarihli ve 26040 sayılı Resmi Gazete( 10. Güncelleme 12/11/2014 tarih ve 29173 sayılı Resmi Gazete)

TMS 18 Hasılat, 09/12/2005 tarih ve 26018 sayıl1 Resmi Gazete ( 8. Güncelleme 30/12/2012 tarih ve 28513 say1l Resmi Gazete)

TMS 36 Varlıklarda Değer Düşüklüğü, 18/03/2006 tarih ve 26112 sayılı Resmi Gazete ( 20. Güncelleme 12/11/2014 tarih ve 29173 sayılı Resmi Gazete)

TMS 38 Maddi Olmayan Duran Varlıklar, 17/03/2006 tarih ve 26111 sayılı Resmi Gazete (12.Güncelleme 18/09/2014 tarih ve 29123 sayılı Resmi Gazete

TMS 40 Yatırım Amaçlı Gayrimenkuller, 17/03/2006 tarih ve 26111 sayılı Resmi Gazete ((8. güncelleme 12/11/2014 tarih ve 29173 sayılı Resmi Gazete) 
